Turda, Marius. “Rózsa, Dávid, Ed-in-Chief. 2014. Portrék a magyar statisztika és népességtudomány történetéböl életrajzi lexikon a XVI. századtól napjainkig ('Portraits from the History of Hungarian Statistics and Demography A Biographical Lexicon from the Sixteenth Century to the Present'). Budapest: Központi Statisztikai Hivatal Könyvtár. 807 pp. Illus. "Hungarian Cultural Studies. e-Journal of the American Hungarian Educators Association, Volume 8 (2015): http://ahea.pitt.edu DOI: 10.5195/ahea.2015.207

\title{
Rózsa, Dávid, Ed-in-Chief. 2014. Portrék a magyar statisztika és népességtudomány történetéböl - életrajzi lexikon a XVI. századtól napjainkig ('Portraits from the History of Hungarian Statistics and Demography - A Biographical Lexicon from the Sixteenth Century to the Present'). Budapest: Központi Statisztikai Hivatal Könyvtár. 807 pp. Illus.
}

\section{Reviewed by Marius Turda, Oxford Brookes University, United Kingdom}

Lexicons, dictionaries and encyclopaedias form a corpus of critical methodological literature essential to any discipline. Yet while their educational and academic role is undisputed they are rarely reviewed in specialized journals. This is unjustifiable considering the enormous amount of research and time that such collaborative works require and their usefulness for researchers and other readers. The Biographical Lexicon under review here is edited by Dávid Rózsa, Deputy Director of the Central Statistical Bureau Library in Budapest. It is the first volume in a new series of studies devoted to the history of statistics in Hungary, initiated by and published under the auspices of the Központi Statisztikai Hivatal, KSH ('Central Statistical Bureau'), whose commendable endeavour will surely be highly praised.

This book brings to light the biographies of notable Hungarian scientists and researchers who either directly or indirectly dealt with demography, statistics and population studies since the sixteenth century to the present. Preceding the biographies of individual authors is an Introduction, written by Gábor Rózsa, a KSH's Department Head, outlining the history of statistics in Hungary and its relevance today. From its modern beginnings during the Enlightenment, statistics, as G. Rózsa rightly points out, served multiple functions, with the first and foremost of them being to provide systematic measurements of the population and of the wealth of the State. Arguably, the first Hungarian author to express an interest in demography and statistics was Miklós Oláh (Nicolaus Olahus), Archbishop of Esztergom and a humanist thinker, whose books Hungaria (1536) and Attila (1537) combined his interest in historical origins with his care about the country's geographical, cultural and social reality. The number of Hungarian contributions to this field grew in the seventeenth and eighteenth centuries, as illustrated by the number of entries covering this period.

Gradually, statistics began to exercise influence beyond the academic sphere, particularly in government administration and in politics. In Hungary, as elsewhere in the Habsburg realm, the process of scientification of statistics can be traced back to the period of reign of King Joseph II (1741-1790), when modern cadastres and cartographic surveys were introduced in order to allow for a more comprehensive system of taxation. It was, however, during the late nineteenth century that statistics became formalized and recognized as a distinct scientific discipline. The Royal Hungarian Statistical Bureau (Országos Magyar Királyi Statisztikai Hivatal) was created in 1871

(cc) $\mathrm{Br}$

ULLS D-Serle 
Turda, Marius. "Rózsa, Dávid, Ed-in-Chief. 2014. Portrék a magyar statisztika és népességtudomány történetéböl életrajzi lexikon a XVI. századtól napjainkig ('Portraits from the History of Hungarian Statistics and Demography A Biographical Lexicon from the Sixteenth Century to the Present'). Budapest: Központi Statisztikai Hivatal Könyvtár. 807 pp. Illus. "Hungarian Cultural Studies. e-Journal of the American Hungarian Educators Association, Volume 8 (2015): http://ahea.pitt.edu DOI: 10.5195/ahea.2015.207

and was shortly followed by the publication of the journal of Magyar statisztikai évkönyv ('Hungarian Statistical Yearbook') in 1872. These accomplishments illustrate the growth of a specialized reading public in Hungary, alongside the emergence of a national school of statistics and demographic studies. The work of renowned statistician József Körösy eloquently exemplifies the proliferation of statistical research in Hungary. Through his work, Körösy contributed significantly to the international recognition of Hungarian statistics, so that by the time of the Eighth International Congress on Hygiene and Demography held in Budapest in 1894 Hungarian statistics was already well established.

Statistics and demography retained an important status during the interwar period and understandably so. Following the tragic years of the First World War and the dismemberment of Hungary, the study of population both within and outside the borders of the new Hungarian State acquired tremendous political importance. New journals were established, including Magyar Statisztikai Szemle ('Hungarian Statistical Review'), to cater for the growing number of the Hungarian specialists, while foreign language journals like Journal de la Société Hongroise de Statistique popularized Hungarian research outside the country. Hungarian statisticians affirmed vigorously the importance of knowing the nature and structure of the population in order to understand its internal dynamic and, ideally, to raise awareness about the nation's resources and needs.

The chronologically arranged biographies in the Lexicon at hand are properly researched and well written as they pay close attention not only to the personal experiences of authors but also to their intellectual sources and to the evolution of their ideas within their given historical and political contexts. Each period in the history of Hungarian statistics, and especially following the enormous demographic changes the country knew during and after each of the two World Wars, is beset with ideological complexities. The individual biographies eloquently reflect the importance of historical events, rightly indentifying the interplay between personal and professional factors in shaping the evolution of Hungarian demography and statistics as both scientific disciplines and tools for creating and reinforcing political legitimacy. Some of the authors included in this Biographical Lexicon, such as József Jekelfalussy, Károly Balás, Sándor Dobrovits, Géza Illyefalvi-Vitéz, Béla Kenéz, Alajos Kovács, Gyula Pikler, Tivadar Szél and Gusztáv Thirring, are familiar names to those dealing with Hungarian history, culture and science; others such as Zoltán Ráth, Dezső Laky, Gyula Marczell and Stefano Somogyi may be less familiar. Also worth mentioning is the contribution of women statisticians, particularly in the second part of the twentieth century. Margit Fórizs, Erzsébet Györkös, Piroska Horváth, Olga Molnár and Júlia Zala are just a few of those women whose work has had a far-reaching impact on the development of Hungarian statistics and demography. Fortunately, each entry is also accompanied by a short bibliography aimed to assist those interested in finding out more about the respective individual.

The interaction between regional academic traditions and the capital, Budapest, is not neglected in the Lexicon; nor is the diverse professional and social background of many of the scientists portrayed in it. The biographies are not only of those who were trained statisticians but also of all those who made significant contributions to Hungarian demography and statistics, even though it was not at all their primary field of expertise. In this category we find Ignác Semmelweis, the early pioneer of antiseptic procedures; physician and geographer Pál Teleki; physicians Lajos Antal and József Madzsar; and anthropologists Mihály Malán and János 
Turda, Marius. “Rózsa, Dávid, Ed-in-Chief. 2014. Portrék a magyar statisztika és népességtudomány történetéböl életrajzi lexikon a XVI. századtól napjainkig ('Portraits from the History of Hungarian Statistics and Demography A Biographical Lexicon from the Sixteenth Century to the Present'). Budapest: Központi Statisztikai Hivatal

Könyvtár. 807 pp. Illus. "Hungarian Cultural Studies. e-Journal of the American Hungarian Educators Association, Volume 8 (2015): http://ahea.pitt.edu DOI: 10.5195/ahea.2015.207

Nemeskéri. By including all these, Dávid Rózsa and his co-editors subscribed to a wide definition of statistics, which includes social dynamics, reproductive patterns and even theories of national health. As most of the biographical entries suggest, statistics in Hungary was always at the confluence of demography and population policy, showing interest in both the Hungarian nation's development and in the social and economic development of Hungary's neighbouring countries that were once part of the Austro-Hungarian Monarchy.

With almost four hundred entries covering five centuries of scholarship, this Biographical Lexicon provides a wealth of new and systematized information. Additional data is provided by the Lexicon's concluding index, which makes it much easier for readers interested in finding a specific concept or an individual author. This Index has, moreover, the beneficial effect of demonstrating the varied and rich conceptualization of statistics in relation to demography, population studies and historical sociology, as well as vis-à-vis cultural and social anthropology.

Considered in its entirety, the biographical Lexicon of Hungarian statistics and demography constitutes a credible achievement in bringing together a great deal of previously unknown information for the use of all those interested in Hungarian science and culture. Although many in Hungary will certainly want to consult it, this detailed selection of biographies will hopefully encourage more research abroad as well, as today's new generations of HungarianStudies researchers might appreciate new and interdisciplinary topics in Hungarian history and culture. 